\title{
Protein Separation from fermentation Broth (E. coli) using polyethersulfone UF and MF membranes
}

\section{Prafulla G Bansod* and VS Sapkal}

Department of Chemical Technology, University Amravati, Maharashtra, India

\begin{abstract}
In this paper, the intracellular E.coli fermentation broth was developed in fermentor. The broths were separated using $0.2 \mu \mathrm{m}$ microfiltration polyethersulfone membranes. The Cells of $E$.coli was retained in microfiltration membrane, were broken in high pressure homogenization. The cells debris and protein were separated using polyethersulfone $0.2 \mu \mathrm{m}$ PES Microfiltration membranes. In microfiltration, cells of E.coli were rejected and proteins collected in permeate sides. After microfiltration, 30KD Ultra filtration membrane was used to separate proteins. About $91.01 \%$ of the proteins were separated by the ultra filtration polyethersulfone membrane.
\end{abstract}

Keywords: Ultrafiltration; Microfiltration; Polyethersulfone; Fermentation; High pressure homogenization

\section{Introduction}

Synthetic polymers such as polysulfone, polyethersulfone, polycarbonate, polyamide, Cellulose acetate etc. are widely used for the preparation of membranes. Polyethersulfone (PES) is a favorable material for membranes as it has properties like resistance to oxidation, acids and alkalis, and excellent biocompatibility. PES has better solubility as compared with polysulfone [1-4]. The wettability of PES can be improved and its biocompatibility enhanced by adding poly (vinyl pyrrolidone) (PVP). This also increased the diffusive transport properties of solute through the membrane. E. coli are commonly used hosts for recombinant product expression because of their ability to produce large quantities of protein quickly and economically. During the past twenty-five years, regulatory requirements have directed industry to use modern technology to improve process purity and

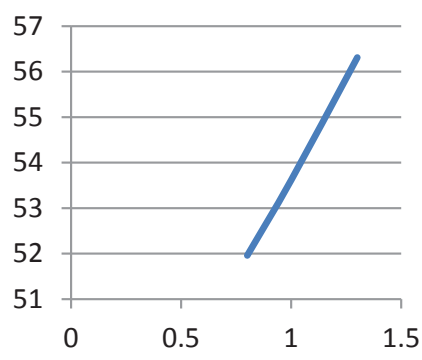

Figure 1: Trans membrane pressure $V s$ concentrate flux.

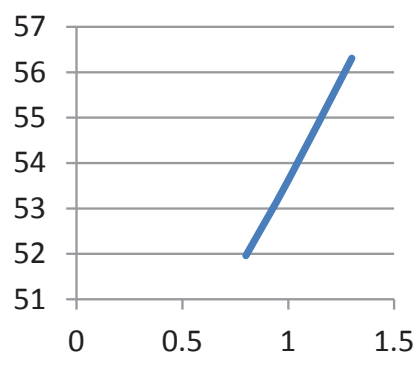

Figure 2: TMP Vs permeate flux.

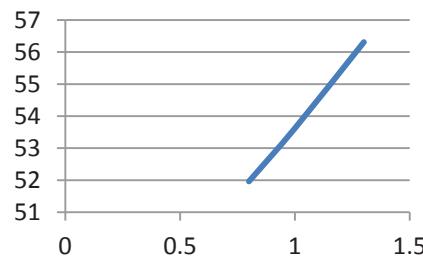

Figure 3: TMP Vs Permeate Recovery.

control. In the same period, the protein industry has become focused on process efficiency, speed, yield and cost. Centrifugation has remained, essentially unchanged since the mid1950s; however recent advances in membrane technologies have facilitated improvements in process purity, control, efficiency, speed, yield and cost.

Cell harvesting, clarification of broth, recycling of cells and separation of cell debris from extracellular products represent important potential applications of membrane technology in the emerging field of biotechnology [1-5]. Membrane separation is a very advanced separation technique as compared to convectional separation method such as rotary filter, sedimentation and centrifugation etc. The importance of the membrane process is due to less energy requirement \& workability at ambient temperature \& pressure, clean technology with ease operation, produce high quality products, greater flexibility in designing system. The types of membrane operation like UF, MF have wide variety of application in fermentation downstream operation treatment in biopharmaceuticals industries for recovery \& separation of valuable components. Typically, a separation specialist takes on the challenge of designing steps to separate the various components

*Corresponding author: Prafulla G Bansod and VS Sapkal Department of Chemical Technology, University Amravati, Maharashtra, India, E-mail: prafulbansod656@rediffmail.com, vssapkal@gmail.com

Received September 06, 2011; Accepted March 29, 2012; Published April 04, 2012

Citation: Bansod PG, Sapkal VS (2012) Protein Separation from fermentation Broth (E. coli) using polyethersulfone UF and MF membranes. J Membra Sci Technol 2:113. doi:10.4172/2155-9589.1000113

Copyright: (C) 2012 Bansod PG, et al. This is an open-access article distributed under the terms of the Creative Commons Attribution License, which permits unrestricted use, distribution, and reproduction in any medium, provided the original author and source are credited. 
Citation: Bansod PG, Sapkal VS (2012) Protein Separation from fermentation Broth (E. coli) using polyethersulfone UF and MF membranes. J Membra Sci Technol 2:113. doi:10.4172/2155-9589.1000113

Page 2 of 3

of a complex fermentation broth that the fermentation-process designers included to maximize fermentation performance. Hence, if the required separation becomes complex and costly, the most efficient fermentation may not necessarily yield the optimum overall process. Typically, $50-70 \%$ of the total production cost in classical processes is due to downstream processing, whereas in fermentation that employs recombinant DNA, the fraction can reach up to $80-90 \%$. This large percentage is often due to separation and purification of the fermentation product.

Escherichia coli are widely used for the expression of mammalian and bacterial proteins. Over expression of these recombinant proteins in E. coli often results in the formation of insoluble protein inclusion bodies (1-7). The first step in the recovery of the intracellular recombinant protein, whether soluble or insoluble, typically involves cell disruption. On a large scale, cell disruption is usually done with either a high pressure homogenizer or a bead mill [1-12]. Increasing the number of passes through a high pressure homogenizer causes greater protein release.

In this paper, $\mathrm{E}$ coli fermentation broth is separated using $0.2 \mu \mathrm{m}$ microfiltration polyethersulfone membranes. Cells of $E$. coli separated from microfiltration passes through high pressure homogenizer. Again $0.2 \mu \mathrm{m}$ microfiltration membranes used to separate cells debris in retained and permeate are feed to $30 \mathrm{KD}$ UF membrane to separate proteins.

\section{Materials and Methods}

Polyethersulfone membrane of molecular weight cut off $30 \mathrm{KD}$, membrane assembly, fermented broth of E.coli, alkaline sodium carbonate solution $(20 \mathrm{~g} / \mathrm{lit} \mathrm{Na} 2 \mathrm{CO} 3$ in $0.1 \mathrm{~mol} / \mathrm{lit}$.Copper sulphatesodium potassium tartrate solution $(5 \mathrm{~g} / \mathrm{lit} \mathrm{CuSO} 4.5 \mathrm{H} 2 \mathrm{O}$ in $10 \mathrm{~g} / \mathrm{lit}$ $\mathrm{Na}, \mathrm{K}$ tartrate). Folin- ciocalteau reagent. Standard protein (Albumin solution $0.2 \mathrm{mg} / \mathrm{ml}$ )

\section{Experimental work}

Fermented broth (E-coli) was used as a feed for (MF/UF) cross flow membrane system. Recovery of protein from the E-coli (fermented broth) involved a number of steps:

1) Microfiltration 2) Homogenization 3) Microfiltration 4) Ultra filtration
Seven liter intracellular E.coli fermentation broth was feed to $0.2 \mu \mathrm{m}$ polyethersulfone microfiltration membrane to concentrate cells of $E$. coli. Concentrated cells were disrupted in homogenizer to separate out intracellular protein. Cell debris and protein were again separated using polyethersulfone $0.2 \mu \mathrm{m}$ MF membranes. Cell debris as retained and proteins in permeate sides of the membranes. Finally proteins were separated in $30 \mathrm{KD}$ ultra filtration polyethersulfone membranes. The concentration of proteins are determined by Lowry's method.

\section{Microfiltration}

Microfiltration: Membrane polyethesulfone $0.2 \mu \mathrm{m}$ (Table 1).

Microfiltration: Feed (cell debris + protein $)=2.635 \mathrm{~L}$ (Table 2$)$.

Ultra filtration: Feed 2.185L (Table 1).

\section{Result and Discussion}

Polyethersulfone microfiltration $0.2 \mu \mathrm{m}$ membrane was used for concentrating and separating cells of E-coli -fermented broth. Seven liters $E$-coli-fermented broth [7L] were used as a feed for microfiltration membrane, where cells of E-coli were concentrated $(635 \mathrm{ml})$ and 6.325 $\mathrm{L}$ as permeated. The concentrated $(0.635 \mathrm{~L})$ cells were passed in high pressure Homogenizer, where intracellular proteins given out from the cells. After Homogenization, cell debris and proteins were separated in $0.2 \mu \mathrm{m}$ microfiltration membranes.2.185L protein were collected in permeate sides and $0.410 \mathrm{~L}$ cells debris collected in retained sides of microfiltration membranes. The permeate which were collected in microfiltration were passed to 30KD PES ultra filtration membranes. The total proteins concentration in permeate were estimated by using Folin-Lowry method of protein assay .The proteins concentration of feed to 30KD UF membranes were found $845 \mu \mathrm{g} / \mathrm{ml}$ and in permeated sides $75 \mu \mathrm{g} / \mathrm{ml}$.The total proteins rejected was found out to be 91.01 percentages in $30 \mathrm{KD}$ polyethersulfone ultra filtration membranes.

The Figure. 1 shows that, when transmembrane pressure increased concentrate flow rate decreased, whereas in Figure 2, showed that when transmembrane pressure increased permeate flow rate also increased continuously.After some times, it was found that permeate flow rate decreased with increase in transmembranes pressure. The resistance creates due to fouling and plugging problems of the membrane and permeates flux decreased (Figure 3 ).

\begin{tabular}{|c|c|c|c|c|c|c|c|}
\hline SR.No & Feed flux rate $\left(\mathrm{L} / \mathrm{m}^{2} \mathrm{~min}\right)$ & Permeate flux rate $\left(\mathrm{L} / \mathrm{m}^{2} \mathrm{~min}\right)$ & Concentrated flux rate $\left(\mathrm{L} / \mathrm{minm}^{2}\right)$ & Inlet press(Bar) & Outlet press(Bar) & TMP & $\%$ Recovery \\
\hline 01 & 126.25 & 63.25 & 62.5 & 1.2 & 0.6 & 0.9 & 50.49 \\
\hline 02 & 129.47 & 69.479 & 60 & 1.4 & 0.8 & 1.2 & 52.66 \\
\hline 03 & 126.354 & 71.35 & 55 & 1.7 & 01 & 1.35 & 56.47 \\
\hline
\end{tabular}

Table 1:

\begin{tabular}{|c|c|c|c|c|c|c|c|}
\hline Sr.no & $\begin{array}{l}\text { Feed flow rate }(\mathrm{L} / \\
\left.\mathrm{m}^{2} \mathrm{~min}\right)\end{array}$ & $\begin{array}{l}\text { Permeate flow rate(L/ } \\
\text { minm }^{2} \text { ) }\end{array}$ & $\begin{array}{l}\text { Concentrated flow } \\
\text { rate }\left(\mathrm{L} / \mathrm{m}^{2} \mathrm{~min}\right)\end{array}$ & Inlet press(Bar) & Outlet press(Bar) & TMP & \%Recovery \\
\hline 01 & 127.08 & 65.83 & 61.25 & 1.2 & 0.6 & 0.9 & 51.80 \\
\hline 02 & 128.64 & 71.145 & 57.5 & 1.4 & 0.8 & 1.1 & 55.30 \\
\hline 03 & 127.5 & 75 & 52.5 & 1.7 & 1 & 1.35 & 58.82 \\
\hline
\end{tabular}

Table 2:

\begin{tabular}{|l|l|l|l|l|l|l|l|l|l|l|l|}
\hline Sr.No & $\begin{array}{l}\text { Feed flow rate(L/ } \\
\left.\text { minm }^{2}\right)\end{array}$ & $\begin{array}{l}\text { Permeate flow } \\
\left.\text { rate(L/minm }{ }^{2}\right)\end{array}$ & $\begin{array}{l}\text { Concentrated flow } \\
\text { rate(L/m²min) }\end{array}$ & Inlet press(Bar) & Outlet press(Bar) & TMP \\
\hline 01 & 130.104 & 67.5 & 62.5 & 1.2 & 0.4 & 0.8 \\
\hline 02 & 132.08 & 70.83 & 61.25 & 1.4 & 0.6 & 01 \\
\hline 03 & 128.75 & 72.5 & 56.25 & 1.7 & 1.3 & 1.3 \\
\hline
\end{tabular}

Table 3: 
Citation: Bansod PG, Sapkal VS (2012) Protein Separation from fermentation Broth (E. coli) using polyethersulfone UF and MF membranes. J Membra Sci Technol 2:113. doi:10.4172/2155-9589.1000113

\section{Conclusion}

E.coli fermentation broth was developed and separated using $0.2 \mu \mathrm{m}$ polyethersulfone microfiltration membranes. The concentrated cells were passed to high pressure homogenizer where intracellular proteins separated out. The cell debris separated using $0.2 \mu \mathrm{m}$ PES microfiltration membranes as retained and proteins collected as permeate side. The proteins were separated in $30 \mathrm{KD}$ PES ultra filtration membrane. The total $90.01 \%$ proteins separated using polyethersulfones UF membranes. Ultra filtration can be successfully used to separate protein and bacteria cells from E.coli fermentation broth. Cells and proteins were retained by the ultra filtration membrane with MWCO of 30,000 Daltons. Increased transmembrane pressures caused higher permeate flux.

\section{Acknowledgement}

We greatly acknowledge the support from Dr. V.S.Sapkal for guidance about the research topic and Sant Gadge baba Amravati, University.

\section{References}

1. Bailey FJ, Warf RT, Maigetter RZ (1990) Harvesting recombinant microbial cells using cross flow filtration. J Enz Microbe Techno 12:647-652.

2. Forman SM, DeBernardez ER, Feldberg RS, Swartz RW (1990) Cross flow filtration for the separation of inclusion bodies from soluble proteins in recombinant Escherichia coli cell lysate. Jc Membrane Sci 48:263-279.
3. Meagher MM, Bartlett RT, Rai VR, Khan FR (1994) The extraction of rlL-2 inclusion bodies from Escherichia coli using cross-flow filtration. Biotechnol Bioeng 43: 969-977.

4. Kroner KH, Nissen N, Ziegler H (1987) Improved dynamic filtration of microbial suspensions. Journals of Bio/technology 5: 921-926.

5. Su ZG, Colton CK (1994) Cross flow membrane filtration, in Harrison, RG (Ed.) Protein Purification Processing Engineering, Marcel Dekker, New York, NY 1994.

6. Gyure DC (1992) set realistic goals for cross flow filtration. Journals of Chem Eng Prog 88: 60-66.

7. Tanaka T, Kamimura R, Fujiwara R, Nakanishi K (1994) Cross flow filtration of yeast broth cultivated in molasses. Biotechnol Bioeng 43:1094-1101.

8. Schlegel VL, Meagher MM () Effects of different membrane modular systems on the performance of cross flow filtration of Pichia pastoris Suspensions. Journal of Membrane Separations in Biotechnology, Marcel Dekker, New York, New

9. Marston $\mathrm{FAO}(1986)$ The purification of eukaryotic polypeptides synthesized in Escherichia coli. Biochem J 240: 1-12.

10. Engler CR (1990) Cell disruption by homogenizer, J. A.Asenjo (ed.), Separation processes in biotechnology. Marcel Dekker, New pp. 95-105

11. Bailey SM, Blum P, Meagher MM (1995) Improved homogenization of recombinant Escherichia coli following pretreatment with guanidine $\mathrm{HCl}$ Biotechnol Prog 11: 533-539.

12. Baker RJ, Fane AG, Fell CJD, Yoo BH (1985) Factors affecting flux in cross flow filtration. Desalination 53: 81-93 genizers Biotechnology Bioeng 36: 1083 1089. 